\title{
Nerolidol: a potential approach in rheumatoid arthritis through reduction of TNF-a, IL-1 $\beta$, IL-6, NF-K $\beta$, COX-2 and anti-oxidant effect in CFA-induced arthritic model
}

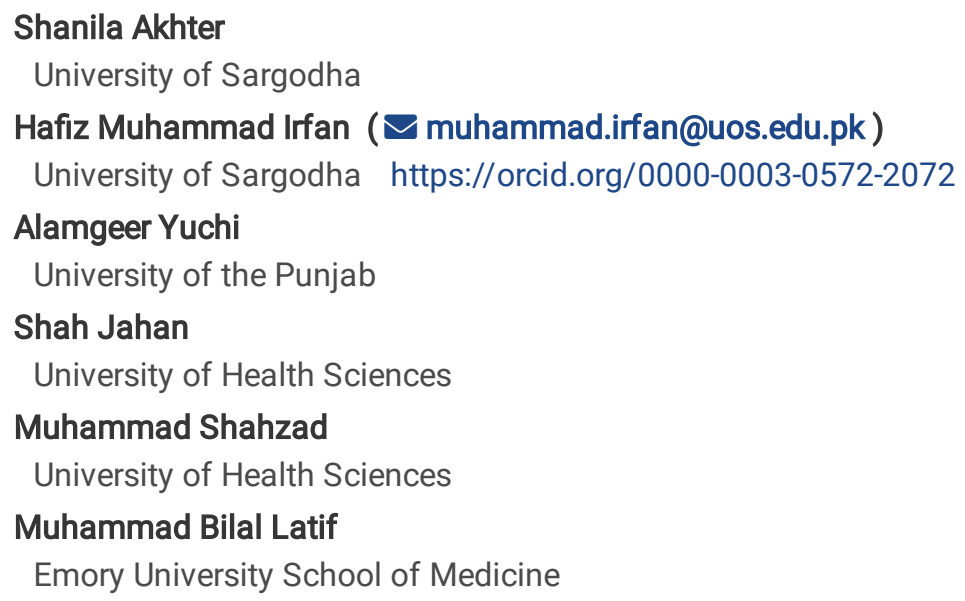

\section{Research Article}

Keywords: Chronic inflammation, Cytokines, Interleukins, Rheumatoid arthritis, RT-qPCR

Posted Date: July 29th, 2021

DOI: https://doi.org/10.21203/rs.3.rs-462402/v1

License: @ (1) This work is licensed under a Creative Commons Attribution 4.0 International License. Read Full License 


\section{Abstract}

Rheumatoid arthritis an autoimmune infectious disorder, is categorized by inflammation and increased level of pro-inflammatory cytokines which are released by immune cells, macrophages or activation of arachidonic acid metabolism. The expression of these cytokines, oxidative free radicals and the activation of COX-2 enzymes are crucial targets for chronic inflammation. On the basis of established anti-inflammatory efficacy of Nerolidol, the primary study was further appraised to determine its efficacy against Freund's complete adjuvant (CFA) rheumatoid model. Arthritis was persuaded by inoculation of $0.1 \mathrm{~mL}$ CFA injection into left hind footpad of rats. Anti-arthritic potential of nerolidol (at 200,400 and $800 \mathrm{mg} / \mathrm{kg}$ doses) was assessed by measuring the paw volume, body weight, serum analysis, histopathological and radio-graphics of ankle joints. Expressions of cytokine's panels like IL-10, IL-4, COX-2, NF- ${ }_{K} \beta$, TNF-a, IL-6, PGE-2 and IL-1 $\beta$ were determined by real time qPCR. Antioxidant enzyme analyses was calculated by measuring the SOD, POD and catalase activity from serum and equated with arthritic control group. Nerolidol prevented the body weight loss, stabilized the biochemical and haematological homeostasis and significantly reduced the paw volume. Furthermore, X-ray and histopathological assessment of ankle joints showed an improvement in the joint structure of rats treated with nerolidol. Besides that, over expression of gene pointers like TNF-a, IL-1 $\beta$, IL-6, NF- ${ }_{K} \beta$, PGE-2 and COX-2 in CFA treated control rats were also reversed with nerolidol. This antiarthritic mechanism was further supported by the increased level of IL-10, IL-4 and serum anti-oxidant activity. The present findings demonstrate that nerolidol reduce the adjuvant arthritis by down-regulating the proinflammatory cytokines and up-regulating the aforementioned anti-inflammatory cytokines and may be used as a therapeutic substance for the management of human rheumatoid arthritis.

\section{Introduction}

Cytokines are involved in many biological processes including activation, differentiation and growth of cells, as well as inflammation (Feldmann et al., 1996). Chronic inflammatory disorders are caused by dysfunctional effects of adoptive and innate immune responses that lead to the induction of cytokines and cause inflammation (Agonia et al., 2020). Inflammatory reaction produces a protective appliance against pathogens and results in the release of chemokine's, cytokines and inflammatory mediators (Lin et al., 2017). Arthritis is an autoimmune inflammatory syndrome that disturbs $1 \%$ of whole population and it is $2-3$ times surplus abundant in womens than mens (Hegen et al., 2008). The augmented level of proinflammatory cytokines like IL-1 $\beta$, TNF-a, NF- $\beta$ and interleukins-6 in acute phase ultimately leads towards bone deformity (Arya et al., 2011). Apart from augmented level of proinflammatory cytokines, increased level of oxidative strain is also an important factor that damages the joints during pathogenesis of RA. These factors increase the production of inflammatory cells especially neutrophils and macrophages, accelerates the release of reactive oxygen sorts in synovial fluid, and cause further tissue destruction (Uttra et al., 2018). Phagocytic macrophages and granulocytes produce hydrogen peroxide and superoxide in excessive amounts. Which degrade lipids by the process known as lipid peroxidation (Biemond et al., 1984). Antioxidants defend the cells against oxidative stress on deoxyribonucleic acid, lipids and protein that has been associated with diseases like RA, diabetes, cancer and Alzheimer, and thus, involve in the improvement of treatment (De Carvalho et al., 2018). Antioxidants act through the inhibition of reactive oxygen species formation in cells. Glutathione peroxidase, catalase and superoxide dismutase are the enzymes that catalysis the hydrogen peroxides and hydro peroxides into harmless molecules including metal ion binding proteins such as caeruloplasmin and transferrin ( that chelates, sesquter iron) and prevent the production of free radicals (Ighodaro and Akinloye, 2018).

Conventional treatment of rheumatoid arthritis includes NSAIDs, corticosteroids, DMARDs that are aimed to decrease the joint inflammation and pain; are not pure anti-arthritic because they do not reduce the B cells and T cells mediated responses (Agarwal, 2010). So there is a need to introduce new novel herbal compound which is most effective and economical against $B$ and $T$ cells mediated response. Phytoconstituents derived from plants that inhibit the expression of cytokines have prospective against arthritis. Henceforth, efforts should be organized to seek out novel beneficial and efficient phytoconstituents which can be used for long standing treatment of RA (Arya et al., 2011).

Nerolidol is derived from Peperomia serpens (Da Silva et al., 2006). Despite that, Peperomia serpens were used to treat pain and inflammation and reduces the expression of IL-1 $\beta$ and TNF-a in mouse model for pain (Fonsêca et al., 2016). Nano encapsulated nerolidol has also been evaluated for its anti-inflammatory role in zymogen induced arthritis in mice and they have also shown the gastro protective effect of nerolidol against ulcer (Trindade et al., 2020). Anti-oxidant effect of nerolidol on hippocampus of mice shows that nerolidol is beneficial against oxidative stress (Neto et al., 2013). Therefore, the aim of current investigation was to appraise the effect of nerolidol in standard model of arthritis (chronic immunological Freund's complete adjuvant rheumatoid arthritis). 
The study was also intended to support the possible mechanism of action of nerolidol at molecular levels and to discover it's efficacy against joint infection.

\section{Materials And Methods}

\section{Drugs and chemicals}

Nerolidol (Sigma-Aldrich, USA), CFA (Sigma-Aldrich, USA), trizole solution, cDNA synthesis kit (Gene Direx, USA), forward / reverse primers (Gene Direx, USA), Cybergreen, deionized water, ethanol, chloroform.

\section{Animals}

Sprague Dawley rats (150-250g) of either sex were used for investigational procedure. Animals were housed at animal house of Department of Pharmacology, College of Pharmacy, University of Sargodha with recommended housing conditions. All animals fed on water and standard diet and they were controlled by following the guidance in accordance with National Research Council. All tests were approved by animal ethics and review committee at University of Sargodha (Approval NO. SU/Pharm/Animal Ethics Approval/2019/215).

\section{Complete Freund's adjuvant induced heumatoid arthritis model}

Animals were separated randomly into six different groups $(n=5)$. The $1^{\text {st }}$ group designated as normal control group and $2^{\text {nd }}$ group (arthritic control group) received $2 \%$ tween $80(3 \mathrm{~mL} / \mathrm{kg})$. The $3^{\text {rd }}$ group (standard group) was given naproxen $20 \mathrm{mg} / \mathrm{kg}$ while $4^{\text {th }}, 5^{\text {th }}$ and $6^{\text {th }}$ group served as treatment groups and received 200,400 and $800 \mathrm{mg} / \mathrm{kg}$ of nerolidol respectively. Arthritis was persuaded by inoculation of $0.1 \mathrm{~mL}$ of CFA injection (containing $1 \mathrm{mg} / \mathrm{mL}$ of heat killed $M$. tuberculosis in $0.15 \mathrm{~mL}$ mono-oleate and $0.85 \mathrm{~mL}$ paraffin oil) into left hind footpad of each rats except normal control group. The day of CFA shot was served as 0 day. The oral administration of different doses to treatment groups was continued for 28 days consecutively. Arthritis in all groups were evaluated by recording various factors (Mahdi et al., 2018).

\section{Evaluations of arthritis from body weights and paw volume of rats}

During the period of treatments, body weight of each rat was observed at every $7^{\text {th }}$ day. Paw size/oedema was measured using digital plathysmometer. Percent inhibition in paw oedema /size was calculated by following this equation.

$$
\text { Percent inhibition }=\frac{v c-v t}{v c} \times 100
$$

"VC" and "VT" are the paw volume of arthritic control and treatment group.

\section{Assessment of arthritis from serum and blood}

At $28^{\text {th }}$ day, all rats were sacrificed and through cardiac puncture blood was collected for the assessment of biochemical and haematological markers comprising WBCs, RBCs, Hb, c-Reactive Proteins, RF, ESR, Platelets, ALP, SGOT, SGPT, Creatinine and urea. These tests were performed at diagnostic center, University of Sargodha (Hassan et al., 2019).

\section{Estimation of mRNA expression levels of TNF-a, IL-1 $\beta$, IL-6, COX-2, IL-4, NF-K $\beta$ and IL-10.}

Collected blood samples were used for appraisal of expression of mRNA TNF-a, IL-1 $\beta$, IL-6, COX-2, NF-K $\beta$, IL-4, and IL-10. TRIzol method was used for the extraction of total RNA from blood. According to this method, into 500uL of blood, $700 \mathrm{uL}$ of trizole solution was added. It was mixed gently and incubated it for 10 minutes. Then 200uL of chloroform was added into it. Shake thoroughly and placed it in the centrifuge machine for 15 minutes at $12000 \mathrm{rpm}$ and $4^{\circ} \mathrm{C}$. The aqueous layer was taken and then added $500 \mathrm{uL}$ of isopropanol into it and again mixed vigorously. Samples were incubated for 10 minutes and retained it in the centrifuge machine at $12000 \mathrm{rpm}$ and $4{ }^{\circ} \mathrm{C}$ for 15 minutes. Discarded the supernatant solution and the RNA pellet was washed with absolute ethanol. Air dried the RNA pellet and added $30 \mathrm{uL}$ of purified water into it and then quantified the RNA from Nano drop reader. After this, cDNA was synthesized by following the kit manufacturer procedure (Gene- Direx). In brief, 1uL of RNA solution, 1uL of oligo (dT) 20, 1uL of dNTP Mix and then RNA free water was added into it. The reaction mixture was heated at $65^{\circ} \mathrm{C}$ for $3-5$ minutes, spin it and placed promptly 
on frost. Then added $4 \mathrm{uL}$ of $1^{\text {st }}$ strand buffer, $1 \mathrm{uL}$ DTT, $1 \mathrm{uL}$ of Script RTase and finally made volume up to $20 \mathrm{uL}$. Incubated it for 30-60 minutes at $50^{\circ} \mathrm{C}$ and the enzyme was inactivated at $70^{\circ} \mathrm{C}$ for 15 minutes.

Real time quantitative PCR was used to intensify and quantify the reaction by using Bio-Rad scheme in Pharmacology department, University of Health Sciences, Lahore. Afterwards, templates of cDNA were mixed with qPCR master mix and added the specific primers of genes, nuclease free water, and then placed it in a thermal cycler for 45 cycles with denaturation temperature at $95^{\circ} \mathrm{C}$, annealing at $56^{\circ} \mathrm{C}$, extension at $72^{\circ} \mathrm{C}$ and then terminated the reaction at $72^{\circ} \mathrm{C}$. Various markers of genes were nominated from Ensemble Genome Browser for determination of specific gene primers physically by using Input primer 3 (v. 0.4.0.) which is available online software. The sequences of primers are provided in Table1 (Shabbir et al., 2016, Lim et al., 2017).

\section{ELISA (Enzyme linked immuno-sorbent assay) for Prostaglandin $E_{2}$}

ELISA test was performed for quantitative identification of rat Prostaglandin $E_{2}$ in serum samples according to kit manufacturer procedures (rat Prostaglandin $\mathrm{E}_{2}$ ELISA kit, Bio-assay technology laboratory having Cat No. E0504Ra, standard curve range = $0.05 \mathrm{ng} / \mathrm{ml}-15 \mathrm{ng} / \mathrm{ml}$, size $=96$ wells, sensitivity $=0.026 \mathrm{ng} / \mathrm{ml}$ ). By adding acidic solution, reaction was terminated and absorbance was measured at $450 \mathrm{~nm}$ (micro-plate reader with $450 \pm 10 \mathrm{~nm}$ ).

\section{Estimation of peroxidase antioxidant enzyme activity}

Peroxidase activity was measured by determining its capability to decrease hydrogen peroxide at wavelength of $470 \mathrm{~nm}$ (Zia et al., 2011). The $0.06 \mathrm{~mL}$ of enzyme extract was added in $3 \mathrm{~mL}$ of buffer substrate solution that comprised of $47 \mathrm{~mL}$ of phosphate buffer $(0.2 \mathrm{M}), 0.7 \mathrm{~mL}$ of guaiacol and $0.32 \mathrm{~mL}$ of $\mathrm{H}_{2} \mathrm{O}_{2}$. After three minutes of enzyme reaction, optical density was measured at $470 \mathrm{~nm}$ spectrophotometer against blank (phosphate buffer guaiacol). Peroxidase activity was measured by using the undermentioned formula.

$$
\text { Peroxidase activity }(\mathrm{U} / \mathrm{mL})=\frac{\Delta A}{26.6 \times 0.06 \times 3.0}
$$

$A=$ Absorbance at $470 \mathrm{~nm}, 26.6=$ extinction coefficient of guaiacol $\left(\mathrm{Mm}^{-1} \mathrm{~cm}^{-1}, 0.06=\right.$ volume of enzyme extract $(\mathrm{mL}), 3.0=$ volume of phosphate buffer $(\mathrm{mL})$

\section{Estimation of catalase antioxidant enzyme activity}

Assay was performed for determining the catalase activity of antioxidant enzymes and its ability was checked to reduce $\mathrm{H}_{2} \mathrm{O}_{2}$ at $240 \mathrm{~nm}$. Reaction mixture was comprised of $3.0 \mathrm{~mL}$ of $\mathrm{K}_{2} \mathrm{PO}_{4}$ buffer $(50 \mathrm{Mm}, \mathrm{pH} 7), 0.1 \mathrm{~mL}$ of hydrogen peroxide $(30 \mathrm{Mm})$ and $0.1 \mathrm{~mL}$ of enzyme extract. Absorbance was observed after 3 minutes of reaction time at 240nm (Chance and Maehly, 1955).Catalase activity was determined by given formula

$$
\text { Catalase activity }=\frac{\Delta A 3}{0.04 \times 0.01} \times 3
$$

$\mathrm{A} 3=$ Absorbance at 240nm, 0.04= Extinction coefficient for $\mathrm{H} 2 \mathrm{O} 2\left(\mathrm{M}^{-1} \mathrm{CM}^{-1}\right)$

\section{Evaluation of superoxide dismutase}

The SOD bustle was performed to check its ability to inhibit the photo reduction of nitro-blue tetrazolium. This test was performed by adopting the protocol with slight modification as discussed by Worthington 1988. Assay mixture was contained $1 \mathrm{~mL}$ of $0.0067 \mathrm{M}$ potassium phosphate buffer $(7.8 \mathrm{pH}), 0.05 \mathrm{~mL}$ extract of enzyme and $0.016 \mathrm{~mL}$ of $0.012 \mathrm{mM}$ solution of riboflavin. The reaction mixture was incubated in a light box for 12 minutes. After that, $0.067 \mathrm{~mL}$ of EDTA/NaCN solution and $0.033 \mathrm{~mL}$ of nitroblue tetrazolium solution was added into the reaction mix. After 30 second of reaction time, the absorbance was observed against blank through spectrophotometer at wavelength of $560 \mathrm{~nm}$. The activity of SOD was calculated by under mentioned formula:

Percent inhibition $=\frac{A(\text { Blank }) A(\text { Sample })}{A(\text { Blank })} \times 100$ 
Histopathological assessment of ankle joints

At the end of the treatment, ankle joints of arthritic control and treated rat paws were collected and static in $10 \%$ solution of formalin for the assessment of histopathology of joints (Shabbir et al., 2014).

\section{Radio graphical assessment of joints}

The legs were removed at knee joints and were subjected for radio graphical assessment with computerized radio graphical system (Toshiba 630 M) (Uttra and Hasan, 2017).

\section{Results}

\section{Effect of nerolidol on morphological deviations and paw volume}

The results specified in Fig. 1 describe that treated groups revealed a significant increase $p<0.01$ ) in paw oedema on day- 1 but paw volume decreased significantly $(p<0.001)$ throughout the period. A significant reduction $(75.99,79.97$, and $81.54 \%)$ in paw volume was detected on 28 day of treatment for the dose of 200,400 and $800 \mathrm{mg} / \mathrm{kg}$, respectively. Moreover, primary marks of chronic inflammation like arthralgia, redness, immobility and swelling of joints were substantially low in rats treated with nerolidol and naproxen sodium, respectively, compared to arthritic control. There was a noteworthy reduction in body weight from $207.00 \pm 13.20$ to $152.60 \pm 15.29 \mathrm{~g}$ that was observed in arthritic rats during the treatment period. However, significant upsurge in weight was observed in rats treated with nerolidol at 200,400 and $800 \mathrm{mg} / \mathrm{kg}$ on $28^{\text {th }}$ day of treatment. Major difference was found in weight gain when dose doubled from $200 \mathrm{mg} / \mathrm{kg}$ as described in Fig. 2 on day 7.

\section{Effect of nerolidol on biochemical and haematological parameters}

Haematologic alteration was observed in injected CFA arthritic control rats. Among them significant decline in hemoglobin RBCs count, increase in value of platelets, WBCs and ESR, ALP, SGPT, SGOT, creatinine, urea and C-reactive proteins had documented. Oral administration of nerolidol significantly increased the RBCs and hemoglobin while noticeably reduction in the liver enzymes, WBCs, C reactive proteins, ESR, Platelets, creatinine and urea was observed equated to the arthritic control rats as revealed in Table 2 . These results showed protective effects against the signs of nephrotoxicity and hepatotoxicity at doses of 200, $400 \mathrm{and} 800 \mathrm{mg} / \mathrm{kg}$. Moreover, nerolidol significantly decreased the RF values in CFA injected rats.

\section{Nerolidol inhibits the mRNA expression level of TNF- $a$, IL-6, IL-1 $\beta$, COX-2, NF- ${ }_{K} \beta$, and induces the expression of IL-10 and IL-4}

On $28^{\text {th }}$ day of treatment, blood was collected and RT-qPCR was performed for the evaluation of different inflammatory cytokines. Augmented manifestation of TNF-a was identified in diseased control rats $(6.98 \pm 0.26)$ and marked reduction in TNF-a was noticed in nerolidol treated rats at 200,400 and $800 \mathrm{mg} / \mathrm{kg}(3.09 \pm 0.28,2.84 \pm 0.23$ and $2.67 \pm 0.16)$ respectively and overall percentage inhibition was $16.6 \%$. Treated rats with nerolidol and naproxen revealed $(p<0.001)$ significant decline in IL-1 $\beta(3.14 \pm 0.204,2.93 \pm 0.22,1.97 \pm 0.04$ and $3.14 \pm 0.17)$ normalized with adjuvant control rats. Similarly, a noticeable decrease in IL-6 was $2.87 \pm 0.08,2.48 \pm 0.18$ and 1.92 \pm 0.12 in rats treated with nerolidol 200,400 and $800 \mathrm{mg} / \mathrm{kg}$ respectively as compared to arthritic control rats $(3.5 \pm 0.32)$. We found a prominent decrease $(p<0.001)$ in the expression of COX-2 in rats treated with nerolidol $200 \mathrm{mg} / \mathrm{kg}(3.72 \pm 0.15), 400 \mathrm{mg} / \mathrm{kg}(3.26 \pm 0.09)$ and $800 \mathrm{mg} / \mathrm{kg}(3.12 \pm 0.097)$ as compared to expression of COX-2 in arthritic rats (7.58 \pm 0.408$)$. Besides, significant reduction in NF-k $\beta$ $(2.6 \pm 0.17,2.56 \pm 0.08,2.0 \pm 0.07,3.0 \pm 0.09)$ was found in nerolidol and naproxen treated rats as equated to arthritic rats (5.50 \pm 0.17). The level of IL-4 and IL-10 was increased in rats treated with nerolidol $(800 \mathrm{mg} / \mathrm{kg})$ and naproxen verses arthritic rats as shown in Figure $3(A, B, C, D, E$ \& $F)$.

\section{Effect of nerolidol on Prostaglandin $E_{2}$}

The animals treated with nerolidol $(p<0.001)$ revealed a significant decrease in level of $P G E_{2}(0.77 \pm 0.04,0.57 \pm 0.02$ and $0.74 \pm 0.037)$ as compared to diseased animals (1.18 \pm 0.03$)$. Maximum effect was achieved at $400 \mathrm{mg} / \mathrm{kg}(51.6 \%)$ of nerolidol in contrast to other doses (Figure 4). Nerolidol at medial dose, it was $14.6 \%$ more effective than naproxen sodium $20 \mathrm{mg} / \mathrm{kg}(0.74 \pm 0.08)$. 
The nerolidol by oral administration at the doses of 200,400 and $800 \mathrm{mg} / \mathrm{kg}$, increased the antioxidant enzyme activity of SOD by $28.76,33.66$ and $44.76 \%$ respectively and induced the protective defense mechanism inside body. Catalase is also an alternative enzyme that work together with SOD and POD through antioxidant defense system of enzymes that breakdowns the $\mathrm{H}_{2} \mathrm{O}_{2}$ into $\mathrm{O}_{2}$ and water that protects the cell from $\mathrm{O}_{2}$ toxicity and lipid peroxidation. Nerolidol at $800 \mathrm{mg} / \mathrm{kg}$ shows significant increase $(p<0.001)$ in enzyme activity of catalase (47.41\%). Similarly, peroxidase activity was $67.17 \%$ at $200 \mathrm{mg}$ dose of nerolidol for 28 days as compared to arthritic control. It was found that the highest concentration of nerolidol was $1.5 \%$ more effective than naproxen sodium.

\section{Effects of nerolidol on histopathological assessment of rats ankle joints}

Evaluation of histopathology of ankle joint was conceded at day 28 of treatment. Histopathology of normal control rats showed that they exhibited normal joint space with intact articular cartilage and synovial tissues having no signs of inflammation with compact arrangements of cells. Ankle joint of arthritic control rats showed noticeable synovial lining, distinct propagation of synoviocytes and incursion of inflammatory cells with granulous and pannus development. Similarly, the erosive changes in bone and cartilage as well as deposition of collagen fibers were also observed in arthritic control groups (Figure 5). However, naproxen (20mg/kg) showed mild incursion of inflammatory cells, cartilage destruction, and thickening of synovial intergalactic space and decreased pannus development. Also, oral administration of nerolidol at $800 \mathrm{mg} / \mathrm{kg}$ showed considerable fortification against proliferation of vascular lesions, limited space between joints, cartilage destruction and small number of inflammatory cells with no pannus development that resemble to a very much normal architecture of joints. Whereas, the $400 \mathrm{mg} / \mathrm{kg}$ dose of nerolidol showed a moderate cartilage destruction with little cellular invasion and pannus formation. Alternatively, nerolidol treated rats with $200 \mathrm{mg} / \mathrm{kg}$ exhibited little reduction in cartilage with minor invasion of inflammatory cells and no formation of pannus.

\section{Effect of nerolidol on radio graphical changes}

The radio graphical examination is useful for the analysis of rheumatoid arthritis for estimation of severity and progression of disease. It has been found that reduction in joint space results in loss of cartilage which initiates the variety of irrational mechanism. X-rays of normal rats showed normal morphology and architecture of cartilage with no swelling around joints. While examination of $x$-rays of arthritic control rats showed that they possessed narrowing of joint space, severe swelling of tissues and bone erosion. In contrast, rats treated with nerolidol $800 \mathrm{mg} / \mathrm{kg}$ exhibited good inhibition of tissue inflammation, bone injury and narrowing of joint space and joint distortion. Likewise, rats treated with nerolidol $400 \mathrm{mg} / \mathrm{kg}$ showed moderate protection against swelling, bone erosion and joint deformity. Similarly, moderate changes occurred in soft tissues of joints with distinct reduction in joint space were also observed in naproxen treated rats as illustrated in Figure 6.

\section{Discussion}

In the present study we have piloted for the 1st time that nerolidol alleviated the CFA arthritis in rat's model of arthritis with pathological structures similar to those of human rheumatism (Lin et al., 2013). Rheumatism is a chronic demagogic autoimmune disorder that targets the cartilage, bones and synovial membrane (McInnes and Schett, 2007). However, exact etiopathagenesis is not yet known but significant validations have confirmed that liberal demolition of bone and cartilage in rheumatism results from synovial neovascularization, increased manifestation of proinflammatory cytokines, osteoclast interceded bone desorption and suspension of cartilage articular matrix mediated by proteinase (Liu et al., 2013). After CFA injection inoculation, inflammatory reactions begin within few days, as secondary lesions come after primary lesions within 2 weeks (Alamgeer et al., 2017). CFA comprised of temperature killed M. tuberculosis dissolved in liquefied paraffin that activates the cell arbitrated immunity, thus accelerates the creation of antibodies (Kim et al., 2016). Mycobacterium are associated in the formation of oedema that may be due to invasion of extracellular fluid and protein debris at the site of inflammation and it is comprised of three phases (induction phase, early synovitis and late synovitis) (Bose et al., 2014, Woode et al., 2009). So, nerolidol significantly reduced the paw volume as compared to arthritic paw volume of rats. It is possible that drug prevented the invasion of fluid into the joints or may be due to its anti-inflammatory effect together with immunomodulatory property by activating the MAPKs pathway (Valdivieso-Ugarte et al., 2019, de Cássia Da Silveira e Sá et al., 2015).

Rheumatoid cachexia was observed in rheumatism characterized by appetite and weight loss that is due to increased production of cytokines, which accelerates the proteolysis and resting metabolism (Adeneye et al., 2014). Proinflammatory cytokines TNF-a, IL-6 and IL-1 $\beta$ are key elements of synovitis and also stimulate the NF-k $\beta$; causes the proteolysis of muscles by activating the proteasome pathways. Overexpression of these pro-inflammatory cytokines induces the anorexia and ultimately muscle loss. Besides that, consumption of glucocorticoids as pharmacological symptomatic treatment of RA might aggravate the rheumatoid cachexia (Masuko, 
2014). The observed cachexia may also be due to muscle proteolysis induced by lysosomal protease that is mediated by decrease absorption of ${ }^{14} \mathrm{C}$-glucose and ${ }^{14} \mathrm{C}$-leucine and also prostaglandin- $\mathrm{E}_{2}$ in the intestines of rats. Anti-inflammatory medications have the capacity to recover the damage caused by the disease (Alamgeer et al., 2017). Similarly they also decreased the expression of proinflammatory cytokines and also resolved the intestinal absorption of rats (Ahsan et al., 2021). In addition, in CFA persuaded arthritis, we also evaluated the biochemical and haematological tests. Anemia is the most common haematological abnormality in rheumatoid arthritis. From the findings of this study, it was apparent that decrease in haemoglobin level and RBCs count in arthritic rats, signify the anemia, that may be due to the destruction of premature RBCs, decreased level of erythropoietin and decreased iron loading in the synovial tissue of reticuloendothelial system and synovial tissues (Alamgeer et al., 2017). Nerolidol caused the notable increase in hemoglobin and RBCs possibly due to the decreased manifestation of NF-K 3 . So it normalized the invasion of inflammatory cells in the synovial fluid and ultimately inhibited the cascade of inflammation (Iqubal et al., 2019). Besides, the level of platelets and WBCs were augmented in arthritic rats due to the excretion of TNF-a and IL-6, (Fig. 5A, 5B) these cytokines initiates acute phase reaction in the rheumatoid arthritis. Though, nerolidol significantly decreased the level of platelets and WBCs in rats by preventing the manifestation of IL- 6 and TNF-a, it is might be due to its immunomodulatory effect.

The overexpression of the pro-inflammatory cytokine causes the accumulation and release of ROS. When the production of reactive species is higher than natural antioxidant defense system, oxidative stress destroys normal physiological function of the DNA, proteins and lipids (Valdivieso-Ugarte et al., 2019). ESR and C-reactive protein are the primary markers for the early analysis of RA. The augmentation of CRP and ESR in the arthritic rats showed the presence of infective proteins in the blood while these levels were considerably reduced $(p<0.001)$ in rats treated with naproxen and nerolidol. Since its values relate with the radiological progression of disease (Babu et al., 2014). Treatment with nerolidol prevented the alleviated reactions of acute phase, when equaled with arthritic control rats. A striking decrease in RF values in treatment groups ensured the protective effect of nerolidol against arthritis. The factor $\mathrm{RF}$ is formed against Fc portion of autoantibody and initiates the immune cascade towards the progression of RA. Moreover, excessive concentration of serum ALP in diseased control group may be due to increased bone erosion and integrity of lysosomal enzymes (Chakraborty et al., 2010). However, administration of different doses of nerolidol to respective groups significantly reduced the ALP, inhibited the atypical rise in SGPT and SGOT that is might be due to reduction in bone loss and improved steadiness of lysosomes.

Proliferating synovial cells, T lymphocytes and macrophages play a crucial role in the progression of arthritis (Goronzy and Weyand, 2001). Proinflammatory cytokines are produced by macrophages and stimulated $T$ cells that is involved in the initiation and progression of rheumatoid arthritis (Vandooren et al., 2009). T cell mediated immune reaction activates the discharge of proinflammatory cytokines and accelerates the formation of antibodies which lead to joint destruction. Over expression of these cytokines causes the irreparable proliferation of tissues, tissue eradication, bone loss and automatic cell death (Zou et al., 2013). Hence, potential antidotes against these cytokines has ability to protect the cells from inflammation (Shin et al., 2016). Therefore, in current investigation effect of nerolidol on expression level of proinflammatory (TNF-a, IL-6, IL-1 $\beta$ ), inflammatory cytokines (NF-k $\beta$, COX-2) and anti-inflammatory cytokines (IL-4, IL-10) were studied by using RT-qPCR. It has been attributed that IL-1 $\beta$ induces the fabrication of (MMPs) matrix metalloproteinase and instigation of osteoclast and ultimately bone erosions (Barksby et al., 2007). In addition, it is described that endogenous inhibitors of MMPs are tissue inhibitors of MMPs (TIMPs). In the manifestation of soluble IL-6R, IL-6 induces the fabrication of TIMPs in synovial fibroblast and cultured chondrocytes. The protective catabolic response produced in tissues are important for extracellular matrix turnover (Silacci et al., 1998). From present findings it was suggested that anticipatory effect of nerolidol on joint demolition was arbitrated to the prevention of induction of IL-6 induced RANKL and formation of MMPs via suppression of IL- 6 followed by osteoclastogenesis. Therefore, therapeutic agents that reduced the IL-6, IL-1 $\beta$ and TNF- $a$ categorized a major invention in the treatment of RA. Augmented level of these proinflammatory cytokines was observed in arthritic control rats, however, significant $(p<0.001)$ decrease in the expression of these cytokines were detected in rats treated with nerolidol at all doses as shown in figure (3B and $3 \mathrm{C}$ ) which suggested its anti-arthritic and anti-inflammatory role. NF-k $\beta$ is involved in the activation and differentiation of osteoclasts which causes development of Th1 response and bone resorption. It has been already been shown that NF-k $\beta$ controls the manifestations of TNF- $a$, later, it works as an potent inducer for the stimulation of NF-k $\beta$ (Shabbir et al., 2016). The existing study elucidates that increased level of NF-k $\beta$ in diseased rats was significantly inhibited by nerolidol on last day of treatment.

The level of COX-2 is increased at the site of injection and they up-regulates the formation of prostaglandin-E2 that mediates the angiogenesis, vasodilation, extravasation of fluid and vascularization in the synovial membrane (Shabbir et al., 2016). Overproduction of inflammatory cytokines causes the increased expression of $\mathrm{PGE}_{2}$. This augmented level of $\mathrm{PGE}_{2}$ accelerates the differentiations of osteoclast and generating the degrading enzymes and hence stimulates the bone erosion, vasodilation and migration of leukocytes at site of inflammation. So, any substance that prevents the generations of aforementioned mediators carries great importance in the 
management of rheumatism (Manan et al., 2020). In current study, increased expression of COX-2 and PGE-2 were noted in diseased controlled rats, however, significant decrease in COX-2 and prostaglandin-E2 were observed in rats treated with nerolidol. Hence, we suggest that nerolidol protected the animals from joint inflammation, may be due to decreased production of prostaglandins and significant inhibition of COX-2 manifestations. Consequently, prevention of arachidonic acid metabolism might be another mechanism of action of nerolidol possessing anti-arthritic activity.

Moreover, IL-4 is an anti-inflammatory cytokine and maintains the production of Th2 cells and inhibits the autoimmune reaction mediated by Th1 cells (Schulze-Koops and Kalden, 2001). The IL-10 also has capability to inhibit the cellular defense mechanism by inactivating the macrophages in response and modifies the synovitis of rheumatoid arthritis (Bozkurt et al., 2006). In the progression of RA, IL-10 not only inhibit the Th1 mediated immune response but also down regulate the function of antigen presenting cells and protects the reliability of joint (Uttra et al., 2018) as same was observed with tested drug as shown in Fig. 3D.

In histopathological assessment, inflamed joints exhibited the continuous migration of polymorph -nuclear leukocytes, macrophages and lymphocytes into joints and synovium. They all produce the inflammatory cytokines in the synovial fluid and joints. Thus, inhibition of migration of macrophages, leukocytes decreased the accumulation of inflamed debris in joints and may have beneficial effect for the protection of joints (Gao and Issekutz, 1994, Wilder et al., 1989). Our histopathological examination suggested that the nerolidol treated groups inhibited the migration of these leukocytes and protects the joint from hyperplasia, joint deformity, pannus formation and destruction of cartilage as shown in Fig. 5. Moreever, X-ray examination revealed that the nerolidol showed significant protection against expansion of subordinate lesions, development of bone desolation and from destruction of cartilage in contrast to arthritic control rats as shown in Fig. 6.

Free radicals and ROS have been stated as mediators in the pathogenesis of RA and cause tissue destruction. In rheumatism, affected articulations are penetrated by different cells like dendritic cells, macrophages and neutrophils. These cells generate the reactive oxygen species that liberate in greater amount at the site of inflammation and overcome the antioxidant enzyme defense system. So, they induce the annihilation of affected joints because during phagocytosis superoxide anions are produced that activate the NF-K $\beta$ dependent manifestation of pro-inflammatory cytokines through second messenger system (Babu et al., 2014). These reactive species cause the peroxidation of lipids, enzyme inactivation, oxidation of proteins, DNA damage and other changes in the cell organelles (Sghaier et al., 2011, Valdivieso-Ugarte et al., 2019). Endogenous enzymes of antioxidant like catalase protect them from tissue damage caused by the reactive species. Catalase involved in lessening the level of hydrogen peroxide in synovial tissues. SOD is the antioxidant enzyme that catalyzes the superoxide into hydrogen peroxide and oxygen free radical which is further catalyzed by catalase enzymes into water and oxygen molecules. In current study, nerolidol was able to up regulate the antioxidant enzymes activity of POD, SOD and CAT and considerably $(p<0.001)$ decreased the lipid peroxidation in the synovial fluid persuaded by release of ROS. This increased the concentration of antioxidant enzymes in the synovial fluid that diminished the destruction of cartilage and tissue deformity in the ankle joint of treated rats. Lipid peroxidation is the process in which poly unsaturated fatty acids undergo the oxidation process and cause functional abnormality in the cell membrane. However, nerolidol decreased the lipid peroxidation level, so they act as an in-vivo antioxidant agents and reduce oxidative stress.

\section{Conclusion}

In a nutshell, oral administration of nerolidol in arthritic rats significantly reduced the paw volume, regained body weight, normalized the altered biochemical and haematological parameters and also inhibited mRNA expression level of the above-mentioned cytokines. So anti-arthritic effect of nerolidol may be due to its capability to decrease the level of NF- ${ }_{K} \beta$, COX-2, PGE2, TNF- $\alpha$, IL-1 $\beta$, IL- 6 and by increasing the level of IL-4 and IL-10 and antioxidant enzyme activity of SOD, POD and CAT. Hence, nerolidol may be recommended as a therapeutic substance for the treatment and management of severity of rheumatism for clinical trials.

\section{Declarations}

\section{Funding}

This study was performed with financial support from Higher Education Commission, Govt. of Pakistan, PIN NO. 518-2MD5-113

\section{Declaration of competing interest}

All authors declare that they do not have any known competing interest. 
Availability of data and material

All the data of this study is transparent.

\section{Code availability}

Not applicable

\section{Author contributions}

The study conceptualization was designed by Dr. Hafiz Muhammad Irfan and Dr. Alamgeer; methodology and research work was developed by Miss Shanila Akhter, manuscript draft was prepared by Dr. Muhammad Bilal Latif, PCR analysis was performed by Dr. Shah Jahan and Dr. Muhammad Shahzad.

\section{Ethics approval}

The experiments conducted on animals were performed according to animal ethics guidelines with approval NO. SU/Pharm/Animal Ethics Approval/2019/215

\section{Consent to participate}

We the authors give consent as a participant in this study.

\section{Consent for publication}

All the contributing authors provide consent for the publication of this study in your journal

\section{References}

1. Adeneye, A.A., Oreagba, A.I., Ishola, I.O. and Kalejaiye, H.A (2014). Evaluation of the anti-arthritic activity of the hydroethanolic leaf extract of Alchornea cordifolia in rats. Afri J Trade Compl Alter Med 11:402-410.

2. Agarwal, S (2010). Newer nutritional basis in the management of rheumatoid arthritis. Elect Phys. 2:33-38.

3. Agonia, I., Couras, J., Cunha, A., Andrade, A.J., Macedo, J. and Sousa-Pinto, B (2020). IL-17, IL-21 and IL-22 polymorphisms in rheumatoid arthritis: A systematic review and meta-analysis. Cyt 125: 813-825.

4. Ahsan, H., Irfan, H. M., Shahzad, M., Asim, M. H., Akram, M., \& Zafar, M. S. (2021). Anti-rheumatic activity of pseudoephedrine (a substituted phenethylamine) in complete Freund's adjuvant-induced arthritic rats by down regulating IL-1 $\beta$, IL- 6 and TNF-a as well as upregulating IL-4 and IL-10. Inflammopharmacol, 1-10.

5. Alamgeer, Niazi, S.G., Uttra, A.M., Qaiser, M.N. and Ahsan, H (2017). Appraisal of anti-arthritic and nephroprotective potential of Cuscuta reflexa. Pharm Bio 55(1): 792-798.

6. Arya, V., Gupta, V.K. and Kaur, R., 2011. A review on plants having anti-arthritic potential. Int J Pharm Sci Rev

7. Res, 7(2):131-136.

8. Babu, N.P., Saravanan, S., Pandikumar, P., Krishna, K.B., Raj, M.K. and Ignacimuthu, S (2014). Anti-inflammatory and anti-arthritic effects of 3-hydroxy, 2-methoxy sodium butanoate from the leaves of Clerodendrum phlomidis Lf. Inflamm Res. 63(2): 127-138.

9. Barksby, H.E., Lea, S.R., Preshaw, P.M. and Taylor, J.J (2007). The expanding family of interleukin-1 cytokines and their role in destructive inflammatory disorders. Clin \& Exp Immunol. 149(2): 217-225.

10. Biemond, P., Swaak, A.J. and Koster, J.F (1984). Protective factors against oxygen free radicals and hydrogen peroxide in rheumatoid arthritis synovial fluid. Arthritis \& Rheum: Off J Am Col Rheumatol. 27(7): 760-765.

11. Bose, M., Chakraborty, M., Bhattacharya, S., Bhattacharjee, P., Mandal, S., Kar, M. and Mishra, R (2014). Suppression of NF-k B p65 nuclear translocation and tumor necrosis factor-a by Pongamia pinnata seed extract in adjuvant-induced arthritis. $J$ immunotoxicol. 11(3): 222-230.

12. Bozkurt, F.Y., Ay, Z.Y., Berker, E., Tepe, E. and Akkuş, S (2006). Anti-inflammatory cytokines in gingival crevicular fluid in patients with periodontitis and rheumatoid arthritis: a preliminary report. Cyt 35(3-4) : 180-185. 
13. Chakraborty, M., Bhattacharya, S., Bhattacharjee, P., Das, R. and Mishra, R (2010). Prevention of the progression of adjuvant induced arthritis by oral supplementation of Indian fresh water mussel (Lamellidens marginalis) aqueous extract in experimental rats. J Ethnopharmacol 132(1) : 316-320.

14. Chance, B. and Maehly, A.C (1955). [136] Assay of catalases and peroxidases. Elsv. 2: 764-775

15. Da Silva, A.C.M., Andrade, E.H.A., Carreira, L.M.M., Guimarães, E.F. and Maia, J.G.S (2006). Essential oil composition of Peperomia serpens (Sw.) Loud. J Essen Oil Res. 18(3) : 269-271.

16. De Carvalho, R.B., De Almeida, A.A.C., Campelo, N.B., Lellis, D.R.O.D. and Nunes, L.C.C ( 2018). Nerolidol and its pharmacological application in treating neurodegenerative diseases: a review. Recent pat biotech 12(3) :158-168.

17. De Cássia Da Silveira e Sá, R., Andrade, L.N. and De Sousa, D.P (2015). Sesquiterpenes from essential oils and anti-inflammatory activity. Natural prod Commun. 10(10) : 1767-1774.

18. Fonsêca, D.V., Salgado, P.R., de Carvalho, F.L., Salvadori, M.G.S., Penha, A.R.S., Leite, F.C., Borges, C.J.S., Piuvezam, M.R., Pordeus, L.C.D.M., Sousa, D.P. and Almeida, R.N (2016). Nerolidol exhibits antinociceptive and anti-inflammatory activity: involvement of the GABA ergic system and proinflammatory cytokines. Fund \& Clin Pharmacol. 30(1) : 14-22.

19. Gao, J.X. and Issekutz, A.C (1994). The effect of ebselen on T-lymphocyte migration to arthritic joints and dermal inflammatory reactions in the rat. Inter $J$ Immunopharmacol. 16(4) : 279-287.

20. Goronzy, J.J. and Weyand, C.M (2001). Thymic function and peripheral T-cell homeostasis in rheumatoid arthritis. Trends Immunol 22(5) : 251-255.

21. Hassan, U.H., Shahzad, M., Shabbir, A., Jahan, S., Saleem, M., Bukhari, I.A. and Assiri, A.M (2019). Amelioration of adjuvant induced arthritis in Sprague Dawley rats through modulation of inflammatory mediators by Ribes alpestre Decne. $J$ Ethnopharmacol. 235 : 460-471.

22. Hegen, M., Keith, J.C., Collins, M. and Nickerson-Nutter, C.L (2008). Utility of animal models for identification of potential therapeutics for rheumatoid arthritis. Annal Rheum Dis. 67(11) : 505-515.

23. Ighodaro, O.M. and Akinloye, O.A (2018). First line defence antioxidants-superoxide dismutase (SOD), catalase (CAT) and glutathione peroxidase (GPX): Their fundamental role in the entire antioxidant defence grid. Alex J Med. 54(4) : 287-293.

24. Iqubal, A., Sharma, S., Ansari, M.A., Najmi, A.K., Syed, M.A., Ali, J., Alam, M.M., Ahmad, S. and Haque, S.E (2019). Nerolidol attenuates cyclophosphamide-induced cardiac inflammation, apoptosis and fibrosis in Swiss Albino mice. Eur J Pharmacol. 863 : 666-677.

25. Kim, W., Park, S., Choi, C., Kim, Y.R., Park, I., Seo, C., Youn, D., Shin, W., Lee, Y., Choi, D. and Kim, M., 2016. Evaluation of antiinflammatory potential of the new ganghwaljetongyeum on adjuvant-induced inflammatory arthritis in rats. Evidence-Based Compl Alter Med. 2016: 294-304.

26. Lim, M.A., Louie, B., Ford, D., Heath, K., Cha, P., Betts-Lacroix, J., Lum, P.Y., Robertson, T.L. and Schaevitz, L (2017). Development of the digital arthritis index, a novel metric to measure disease parameters in a rat model of rheumatoid arthritis. Front Pharmacol. 8 : $818-36$.

27. Lin, N.Y., Beyer, C., GießI, A., Kireva, T., Scholtysek, C., Uderhardt, S., Munoz, L.E., Dees, C., Distler, A., Wirtz, S. and Krönke, G (2013). Autophagy regulates TNFa-mediated joint destruction in experimental arthritis. Annal Rheum Dis. 72(5) : 761-768.

28. Lin, Z., Ge, J., Wang, Z., Ren, J., Wang, X., Xiong, H., Gao, J., Zhang, Y. and Zhang, Q (2017). Let-7e modulates the inflammatory response in vascular endothelial cells through ceRNA crosstalk. Sci Rep. 7(1) : 1-12.

29. Liu, X., Zou, Q., Zeng, B., Fang, Y. and Wei, H (2013). Analysis of fecal Lactobacillus community structure in patients with early rheumatoid arthritis. Current Microbiol 67(2) : 170-176.

30. Mahdi, H.J., Khan, N.A.K., Asmawi, M.Z.B., Mahmud, R., Vikneswaran, A. and Murugaiyah, L (2018). In vivo anti-arthritic and antinociceptive effects of ethanol extract of Moringa oleifera leaves on complete Freund's adjuvant (CFA)-induced arthritis in rats. Integ Med Res. 7(1) : 85-94.

31. Manan, M., Saleem, U., Akash, M.S.H., Qasim, M., Hayat, M., Raza, Z. and Ahmad, B (2020). Antiarthritic Potential of Comprehensively Standardized Extract of Alternanthera bettzickiana: In Vitro and In Vivo Studies. ACS omega, 31, 19478-496.

32. Masuko, K (2014). Rheumatoid cachexia revisited: a metabolic co-morbidity in rheumatoid arthritis. Front Nutr $1: 20-27$.

33. McInnes, I.B. and Schett, G (2007). Cytokines in the pathogenesis of rheumatoid arthritis. Nature Rev Immunol 7(6) : 429-442.

34. Neto, J.D.N., de Almeida, A.A.C., da Silva Oliveira, J., Dos Santos, P.S., de Sousa, D.P. and de Freitas, R.M (2013). Antioxidant effects of nerolidol in mice hippocampus after open field test. Neurochem/ Res. 38(9) :1861-1870.

Page $10 / 17$ 
35. Schulze-Koops, H. and Kalden, J.R (2001). The balance of Th1/Th2 cytokines in rheumatoid arthritis. Best Pract \& Res Clin Rheumatol 15(5) : 677-691.

36. Sghaier, M.B., Skandrani, I., Nasr, N., Franca, M.G.D., Chekir-Ghedira, L. and Ghedira, K (2011). Flavonoids and sesquiterpenes from Tecurium ramosissimum promote antiproliferation of human cancer cells and enhance antioxidant activity: A structure-activity relationship study. Envirn toxicol pharmacol. 32(3) : 336-348.

37. Shabbir, A., Shahzad, M., Ali, A. and Zia-ur-Rehman, M (2014). Anti-arthritic activity of N'-[(2, 4-dihydroxyphenyl) methylidene]-2-(3, 4-dimethyl-5, 5-dioxidopyrazolo [4, 3-c][1, 2] benzothiazin-1 (4H)-yl) acetohydrazide. Eur J Pharmacol. 738: 263-272.

38. Shabbir, A., Shahzad, M., Ali, A. and Zia-ur-Rehman, M (2016). Discovery of new benzothiazine derivative as modulator of pro-and anti-inflammatory cytokines in rheumatoid arthritis. Inflamm. 39(6) : 1918-1929.

39. Shin, T.H., Kim, H.S., Kang, T.W., Lee, B.C., Lee, H.Y., Kim, Y.J., Shin, J.H., Seo, Y., Choi, S.W., Lee, S. and Shin, K (2016). Human umbilical cord blood-stem cells direct macrophage polarization and block inflammasome activation to alleviate rheumatoid arthritis. Cell death \& Dis 7(12) : 442-453.

40. Silacci, P., Dayer, J.M., Desgeorges, A., Peter, R., Manueddu, C. and Guerne, P.A (1998). Interleukin (IL)-6 and its soluble receptor induce TIMP-1 expression in synoviocytes and chondrocytes, and block IL-1-induced collagenolytic activity. J Biol Chem. 273(22) : 13625-629.

41. Trindade, G.D.G.G., Gomes, M.V.L.D., Silva, L.A.S., Grespan, R., Junior, L.J.Q., de Albuquerque Júnior, R.L.C., Shanmugan, S. and de Souza Araújo, A.A (2020). Anti-inflammatory effect of nano-encapsulated nerolidol on zymosan-induced arthritis in mice. Food Cheml Toxicol. 135 : 110958-67.

42. Uttra, A.M. and Hasan, U.H (2017). Anti-arthritic activity of aqueous-methanolic extract and various fractions of Berberis orthobotrys Bien ex Aitch. BMC compl Alter Med 17(1) : 1-16.

43. Uttra, A.M., Shahzad, M., Shabbir, A. and Jahan, S (2018). Ephedra gerardiana aqueous ethanolic extract and fractions attenuate Freund Complete Adjuvant induced arthritis in Sprague Dawley rats by downregulating PGE2, COX2, IL-1 $\beta$, IL-6, TNF-a, NF-kB and upregulating IL-4 and IL-10. J Ethnopharmacol. 224: 482-496.

44. Valdivieso-Ugarte, M., Gomez-Llorente, C., Plaza-Díaz, J. and Gil, Á (2019). Antimicrobial, antioxidant, and immunomodulatory properties of essential oils: A systematic review. Nut 11(11) : 2786-115.

45. Vandooren, B., Noordenbos, T., Ambarus, C., Krausz, S., Cantaert, T., Yeremenko, N., Boumans, M., Lutter, R., Tak, P.P. and Baeten, D (2009). Absence of a classically activated macrophage cytokine signature in peripheral spondylarthritis, including psoriatic arthritis. Arthritis \& Rheum. Offi J Am Col Rheumatol. 60(4) :966-975.

46. Woode, E., Boakye-Gyasi, E., Danquah, C.A., Ansah, C. and Duwiejua, M (2009). in Freund's Adjuvant-Induced Arthritis in Rats. Inter J Pharmacol. 5(3) : 181-190.

47. Zia, M.A., Kousar, M., Ahmed, I., Iqbal, H.M.N. and Abbas, R.Z (2011). Comparative study of peroxidase purification from apple and orange seeds. Afr J Biotech. 10(33) : 6300-6303.

48. Zou, C.J., Zhu, L.J., Li, Y.H., Mo, Y.Q., Zheng, D.H., Ma, J.D., Ou-Yang, X., Pessler, F. and Dai, L (2013). The association between hepatitis B virus infection and disease activity, synovitis, or joint destruction in rheumatoid arthritis. Clin rheumatol. 32(6) : 787795.

\section{Tables}

Table 1: Forward-reverse primers sequences with respect to gene markers used in real time - PCR 


\begin{tabular}{|l|l|l|l|}
\hline $\begin{array}{l}\text { Gene } \\
\text { Markers }\end{array}$ & $\begin{array}{l}\text { Forward } \\
\text { Reverse }\end{array}$ & Sequences & $\begin{array}{l}\text { Base pair } \\
\text { (amplified band) }\end{array}$ \\
\hline IL-1 $\beta$ & $\begin{array}{l}\text { Forward } \\
\text { Reverse }\end{array}$ & $\begin{array}{l}\text { 5'-GCTGTCCAGATGAGAGCATC-3' } \\
\text { 5'-GTCAGACAGCACGAGGCATT-3' }\end{array}$ & 293 \\
\hline IL-6 & $\begin{array}{l}\text { Forward } \\
\text { Reverse }\end{array}$ & $\begin{array}{l}\text { 5'-AGACTTCCAGCCAGTTGCCT-3' } \\
\text { 5'-CTGACAGTGCATCATCGCTG-3' }\end{array}$ & 233 \\
\hline COX-2 & $\begin{array}{l}\text { Forward } \\
\text { Reverse }\end{array}$ & $\begin{array}{l}\text { 5'-GCATTCTTTGCCCAGCACTT-3' } \\
\text { 5'-GTCTTTGACTGTGGGAGGAT-3' }\end{array}$ & 210 \\
\hline TNF- $\alpha$ & $\begin{array}{l}\text { Forward } \\
\text { Reverse }\end{array}$ & $\begin{array}{l}\text { 5'-AGGACACCATGAGCACGGAA-3' } \\
\text { 5'-GGGCCATGGAACTGATGAGA-3' }\end{array}$ & 234 \\
\hline NF-K $\beta$ & $\begin{array}{l}\text { Forward } \\
\text { Reverse }\end{array}$ & $\begin{array}{l}\text { 5'-GCAACTCTGTCCTGCACCTA-3' } \\
\text { 5'-CTGCTCCTGAGCGTTGACTT-3' }\end{array}$ & 203 \\
\hline IL-4 & $\begin{array}{l}\text { Forward } \\
\text { Reverse }\end{array}$ & $\begin{array}{l}\text { 5'-CACCTTGCTGTCACCCTGTT-3' } \\
\text { 5'-CCTGCAGATGAGCTCGTTCT-3' }\end{array}$ & 195 \\
\hline IL-10 & $\begin{array}{l}\text { Forward } \\
\text { Reverse }\end{array}$ & $\begin{array}{l}\text { 5'-GCCCAGAAATCAAGGAGCAT-3' } \\
\text { 5'-CGTAGGCTTCTATGCAGTTG-3' }\end{array}$ & 210 \\
\hline
\end{tabular}

Table 2: Effect of oral administration of nerolidol on biochemical and haematological parameter in CFA induced model

\begin{tabular}{|l|l|l|l|l|l|l|}
\hline $\begin{array}{l}\text { Biochemical } \\
\text { and } \\
\text { hematological } \\
\text { parameters }\end{array}$ & \multicolumn{1}{|c|}{$\begin{array}{c}\text { Arthritic } \\
\text { control } \\
\text { Control }\end{array}$} & $\begin{array}{l}\text { Naproxen } \\
(20 \mathrm{mg} / \mathrm{kg})\end{array}$ & $\begin{array}{l}\text { Nerolidol } \\
(200 \mathrm{mg} / \mathrm{kg})\end{array}$ & $\begin{array}{l}\text { Nerolidol } \\
(400 \mathrm{mg} / \mathrm{kg})\end{array}$ & $\begin{array}{l}\text { Nerolidol } \\
(800 \mathrm{mg} / \mathrm{kg})\end{array}$ \\
\hline $\begin{array}{l}\text { SGOT } \\
(\mathrm{U} / \mathrm{L})\end{array}$ & $149.61 \pm 0.26$ & $110.83 \pm 0.09^{* * *}$ & $125.24 \pm 0.36^{* * *}$ & $134.62 \pm 0.32^{* * *}$ & $127.49 \pm 0.26^{* * *}$ & $120.84 \pm 0.10^{* * *}$ \\
\hline $\begin{array}{l}\text { SGPT } \\
(\mathrm{U} / \mathrm{L})\end{array}$ & $49.95 \pm 0.04$ & $21.05 \pm 0.02^{* * *}$ & $35.03 \pm 0.02^{* * *}$ & $37.33 \pm 0.33^{* * *}$ & $33.72 \pm 0.31^{* * *}$ & $32.29 \pm 0.28^{* * *}$ \\
\hline $\begin{array}{l}\text { Urea } \\
(\mathrm{mg} / \mathrm{dL})\end{array}$ & $37.66 \pm 0.32$ & $18.58 \pm 0.26^{* * *}$ & $27.89 \pm 0.04^{* * *}$ & $28.36 \pm 0.31^{* * *}$ & $26.42 \pm 0.21^{* * *}$ & $22.95 \pm 0.42^{* * *}$ \\
\hline $\begin{array}{l}\text { ALP } \\
(\mathrm{UL} / \mathrm{L})\end{array}$ & $312.32 \pm 0.27$ & $158.58 \pm 0.25^{* * *}$ & $203.00 \pm 1.00^{* * *}$ & $201.65 \pm 0.88^{* * *}$ & $195.44 \pm 2.35^{* * *}$ & $192.07 \pm 0.70^{* * *}$ \\
\hline $\begin{array}{l}\text { CREAT } \\
(\mathrm{mg} / \mathrm{dL})\end{array}$ & $0.99 \pm 0.00$ & $0.46 \pm 0.00^{* * *}$ & $0.58 \pm 0.00^{* * *}$ & $0.63 \pm 0.02^{* * *}$ & $0.57 \pm 0.00^{* * *}$ & $0.51 \pm 0.00^{* * *}$ \\
\hline $\begin{array}{l}\text { CRP } \\
(\mathrm{mg} / \mathrm{dL})\end{array}$ & $39.69 \pm 0.12$ & $3.91 \pm 0.07^{* * *}$ & $12.48 \pm 0.49^{* * *}$ & $13.94 \pm 0.03^{* * *}$ & $10.33 \pm 0.32^{* * *}$ & $8.98 \pm 0.54^{* * *}$ \\
\hline $\begin{array}{l}\text { RF } \\
(\mathrm{IU} / \mathrm{L})\end{array}$ & $35.75 \pm 1.2$ & $6.38 \pm 0.41^{* * *}$ & $9.78 \pm 0.11^{* * *}$ & $11.32 \pm 0.65^{* * *}$ & $9.62 \pm 0.03^{* * *}$ & $8.61 \pm 0.31^{* * *}$ \\
\hline $\begin{array}{l}\text { ESR } \\
(\mathrm{mm} / \mathrm{h})\end{array}$ & $9.58 \pm 0.29$ & $3.55 \pm 0.04^{* * *}$ & $4.88 \pm 0.00^{* * *}$ & $4.98 \pm 0.00^{* * *}$ & $4.82 \pm 0.01^{* * *}$ & $3.96 \pm 0.03^{* * *}$ \\
\hline $\begin{array}{l}\text { PLAT } \\
\left(10^{3} / \mathrm{UL}\right)\end{array}$ & $1321.08 \pm 0.30$ & $941.21 \pm 0.33^{* * *}$ & $963.22 \pm 3.18^{* * *}$ & $983.66 \pm 3.18^{* * *}$ & $963.67 \pm 1.20^{* * *}$ & $955.36 \pm 0.31^{* * *}$ \\
\hline $\begin{array}{l}\text { WBCs } \\
\left(10^{3 / \mu L}\right)\end{array}$ & $14.03 \pm 0.22$ & $8.08 \pm 0.48^{* * *}$ & $12.27 \pm 0.64^{*}$ & $10.97 \pm 0.45^{* * *}$ & $8.33 \pm 0.21^{* * *}$ & $6.96 \pm 0.29^{* * *}$ \\
\hline $\begin{array}{l}\text { RBCs } \\
\left(10^{6 / \mu L}\right)\end{array}$ & $5.25 \pm 0.25$ & $9.30 \pm 0.23^{* * *}$ & $7.10 \pm 0.06^{* * *}$ & $7.58 \pm 0.22^{* * *}$ & $8.10 \pm 0.07^{* * *}$ & $8.48 \pm 0.33^{* * *}$ \\
\hline $\begin{array}{l}\text { Hb } \\
(\mathrm{g} / \mathrm{dL})\end{array}$ & $9.13 \pm 0.09$ & $14.76 \pm 0.06^{* * *}$ & $11.69 \pm 0.30^{* * *}$ & $11.05 \pm 0.03^{* * *}$ & $12.90 \pm 0.03^{* * *}$ & $14.26 \pm 0.25^{* * *}$ \\
\hline
\end{tabular}

Note: Values are expressed as mean $\pm S E M(\mathrm{n}=5)$ followed by one-way ANOVA with Dunnet posttest. $* * * \mathrm{p}<0.001$, the values were significant as compared to arthritic control.

Table 3: Effect of nerolidol and other treatments given for 28 days on antioxidant enzyme activities 


\begin{tabular}{|l|l|l|l|}
\hline Treatment groups & $\begin{array}{c}|c| \\
\text { POD } \\
\text { (U/mg protein) }\end{array}$ & $\begin{array}{c}\text { SOD } \\
\text { (U/mg protein) }\end{array}$ & $\begin{array}{c}\text { CAT } \\
\text { (U/mg protein) }\end{array}$ \\
\hline Arthritic rats & $3.45 \pm 0.14$ & $9.91 \pm 0.21$ & $42.18 \pm 1.68$ \\
\hline Normal rats & $15.26 \pm 0.20^{* * *}$ & $20.00 \pm 0.00^{* * *}$ & $95.33 \pm 1.76^{* * *}$ \\
\hline $\begin{array}{l}\text { Naproxen } \\
(20 \mathrm{mg} / \mathrm{kg})\end{array}$ & $13.83 \pm 0.02^{* * *}$ & $14.76 \pm 0.10^{* * *}$ & $67.07 \pm 0.41^{* * *}$ \\
\hline $\begin{array}{l}\text { Nerolidol } \\
(200 \mathrm{mg} / \mathrm{kg})\end{array}$ & $10.51 \pm 0.07^{* * *}$ & $13.91 \pm 0.06^{* * *}$ & $63.73 \pm 0.96^{* * *}$ \\
\hline $\begin{array}{l}\text { Nerolidol } \\
(400 \mathrm{mg} / \mathrm{kg})\end{array}$ & $12.95 \pm 0.03^{* * *}$ & $14.94 \pm 0.03^{* * *}$ & $73.91 \pm 1.03^{* * *}$ \\
\hline $\begin{array}{l}\text { Nerolidol } \\
(800 \mathrm{mg} / \mathrm{kg})\end{array}$ & $14.05 \pm 0.03^{* * *}$ & $17.94 \pm 0.03^{* * *}$ & $80.21 \pm 0.28^{* * *}$ \\
\hline
\end{tabular}

Values are articulated as mean \pm SEM followed by one-way ANOVA with Dunnett posttest ${ }^{* * *}$ p $\left.<0.001\right)$

\section{Figures}

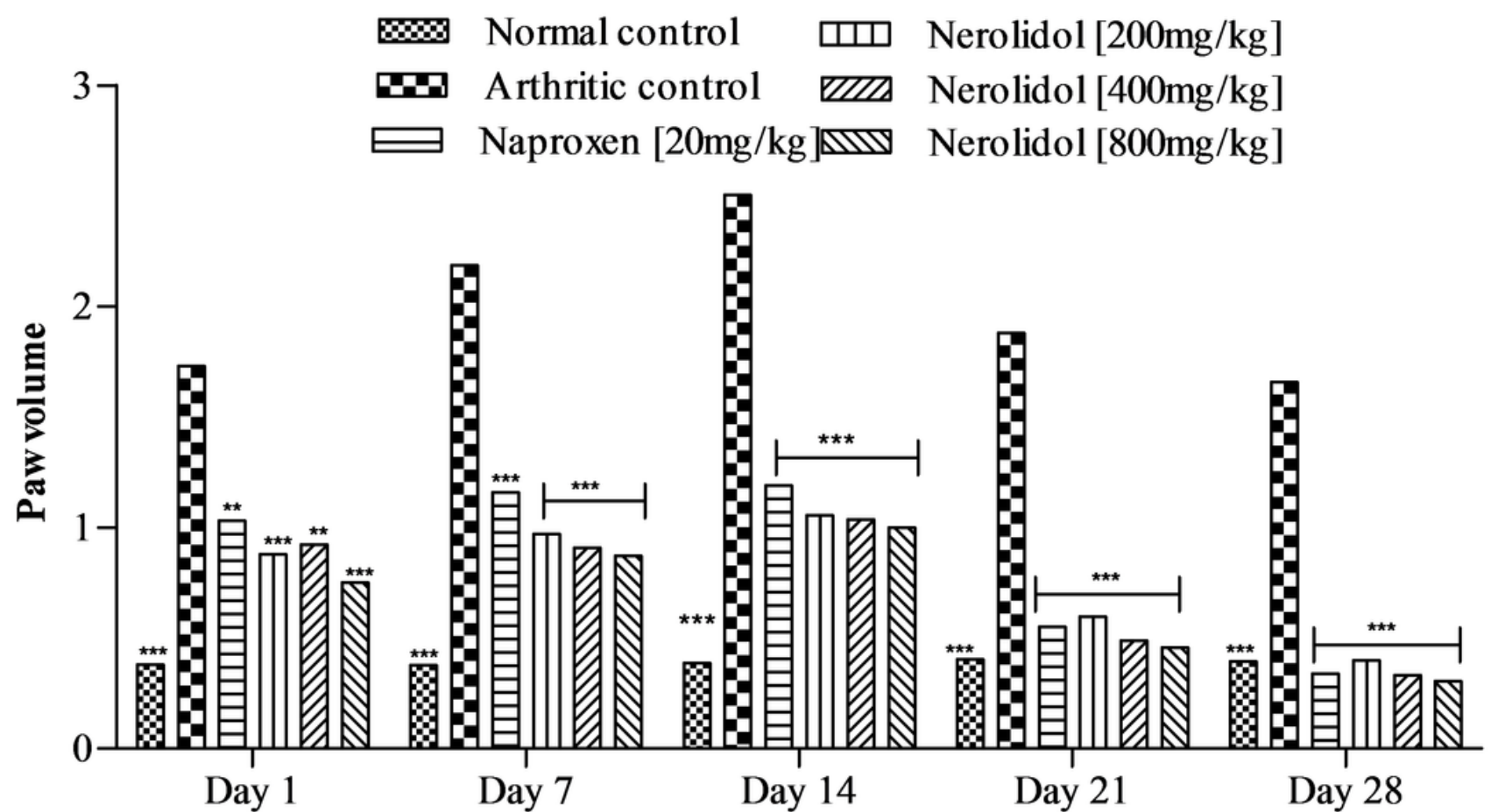

Figure 1

Effect of different doses of nerolidol given for 28-days on paw volume induced by CFA. Result was followed by Two way ANOVA using graph pad prism with Bonferroni posttest whereas ${ }^{\star \star *} p<0.001,{ }^{\star \star} p<0.01$ 


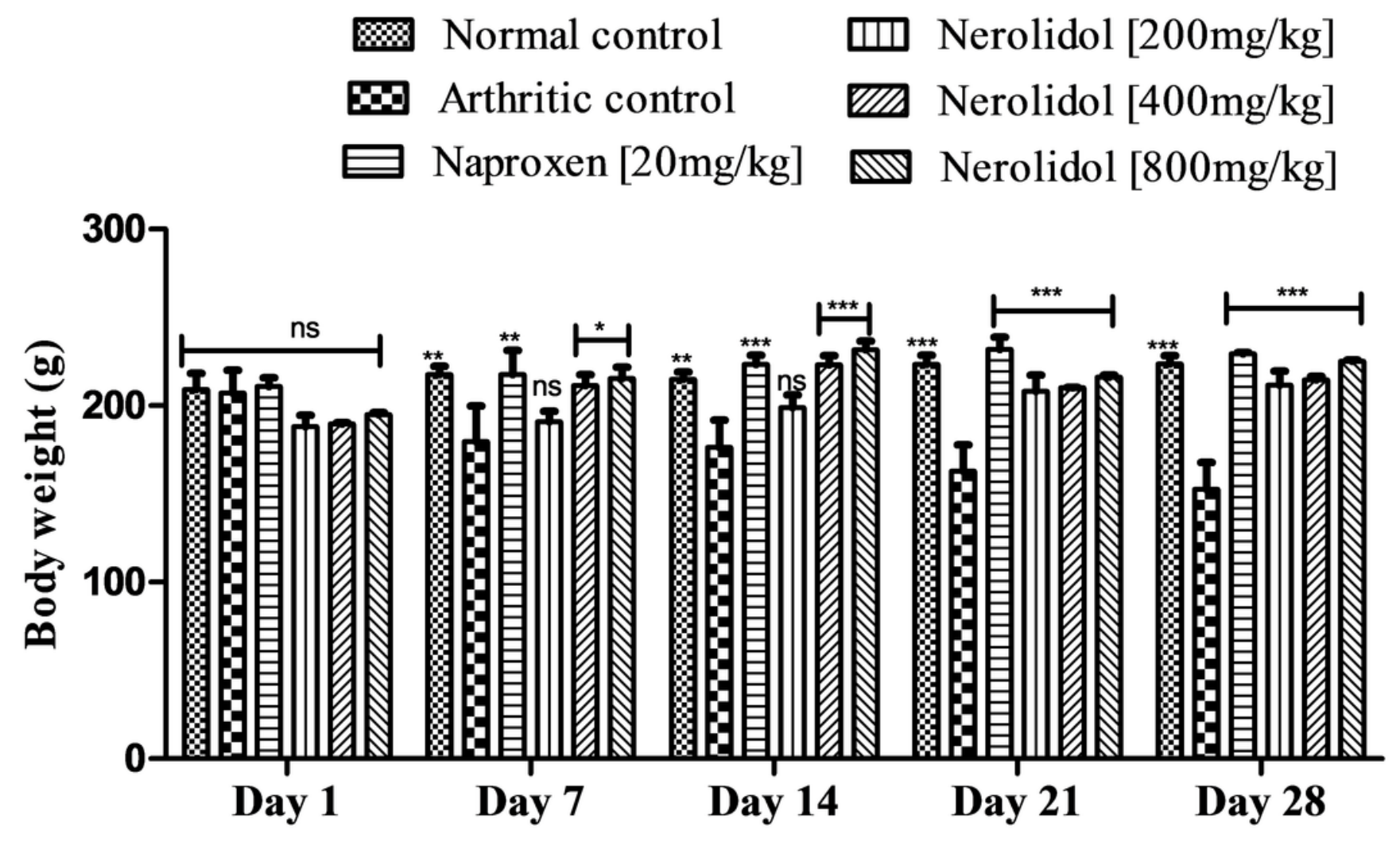

Figure 2

Effect of different doses of nerolidol given for 28-days on body weight of CFA-induced rats. Result was followed Two way ANOVA using graph pad prism with Bonferroni posttest whereas $* \star * p<0.001, * \star p<0.01$ and $* p<0.05$. 

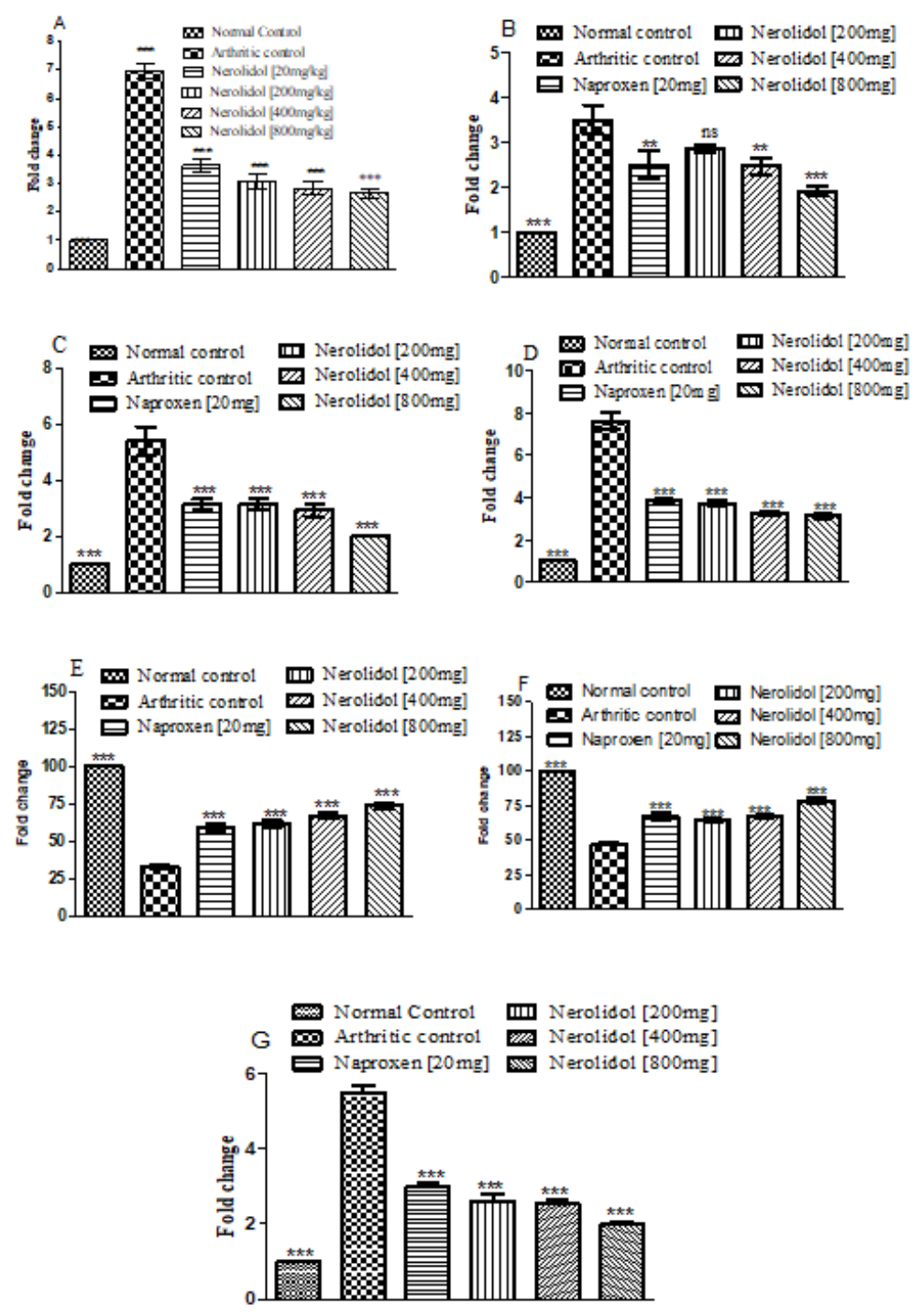

Figure 3

Expression of cytokines assessed by RT-qPCR treated with nerolidol for 28 days in CFA-induced model. Analyzed by one-way ANOVA

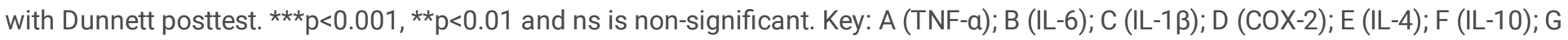
(NF-K $\beta)$ 


\section{$\mathrm{PGE}_{2}$}

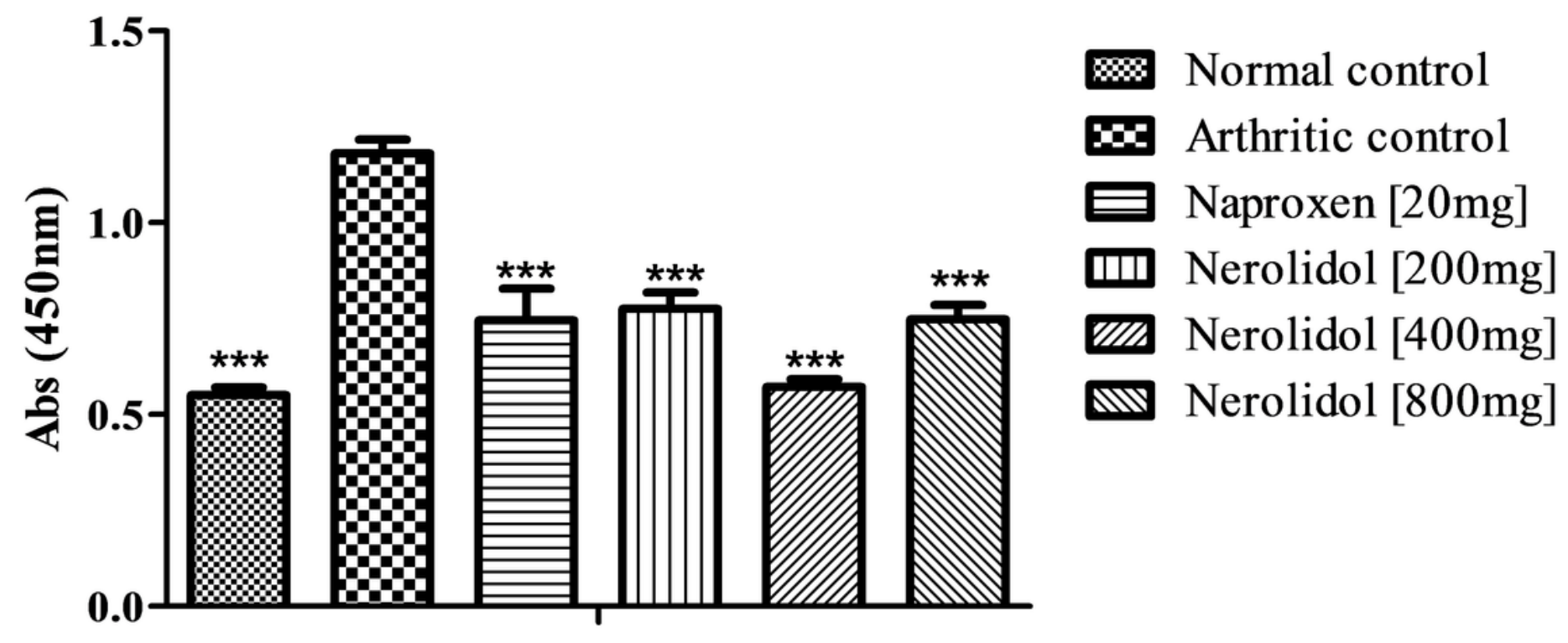

Treatments

Figure 4

Effect of daily oral administration of nerolidol $(200,400$ and $800 \mathrm{mg} / \mathrm{kg})$ and Naproxen for 28 days on Prostaglandin E2. The results were analyzed by using Mean \pm SEM followed by One-way ANOVA was performed $(n=5)$, where ${ }^{* \star *} p<0.001$.
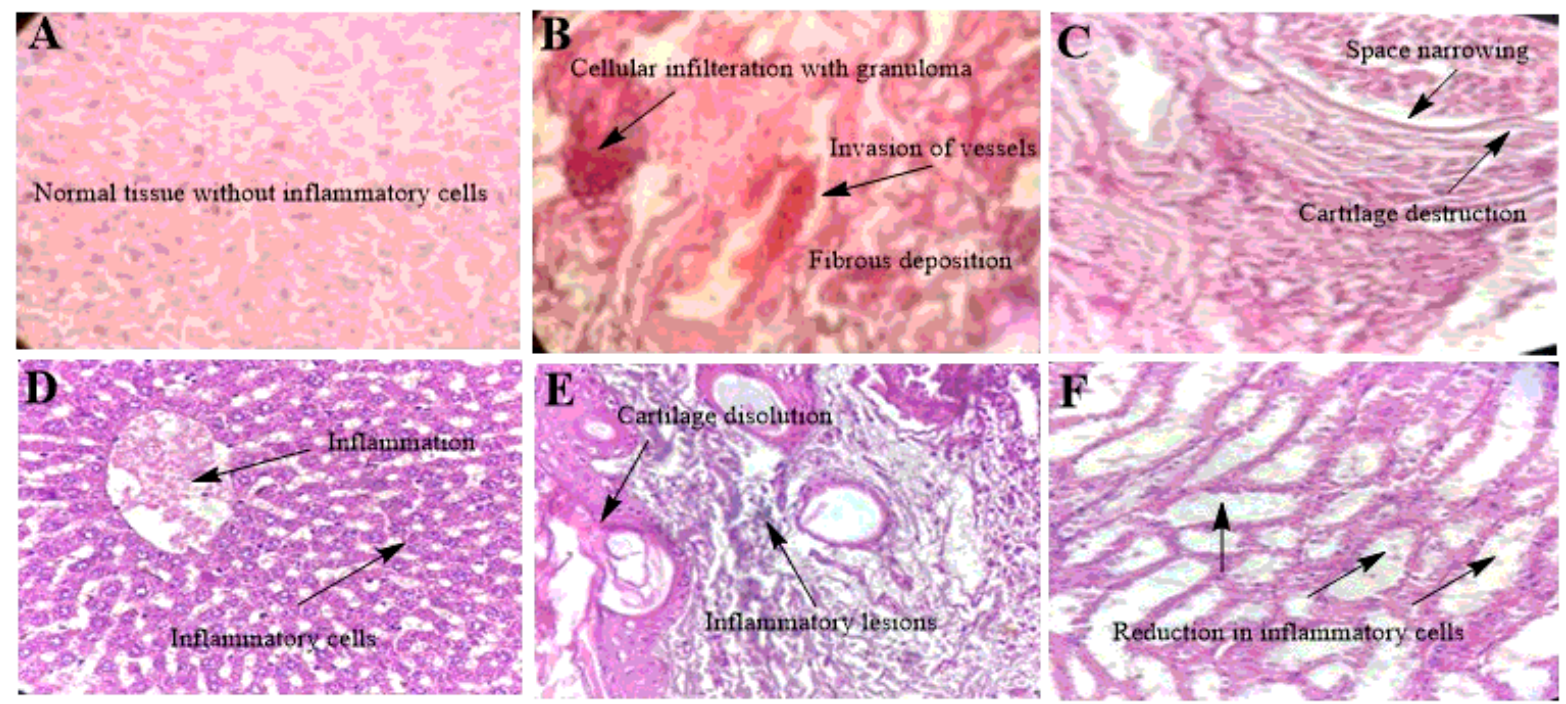

Figure 5

Effect of oral administration of nerolidol for 28 days on histological variations in frend's induced arthritis. Whereas A represents slide of normal rat possessing no inflammatory cells, B represent histology of arthritic control rat showing vessels invasions and fibrous deposition, while C, D, E and F represents slides of treated rats with naproxen and different doses of nerolidol $(200,400 \mathrm{and} 800 \mathrm{mg} / \mathrm{kg}$ ) showing reduction in inflammatory cells. 

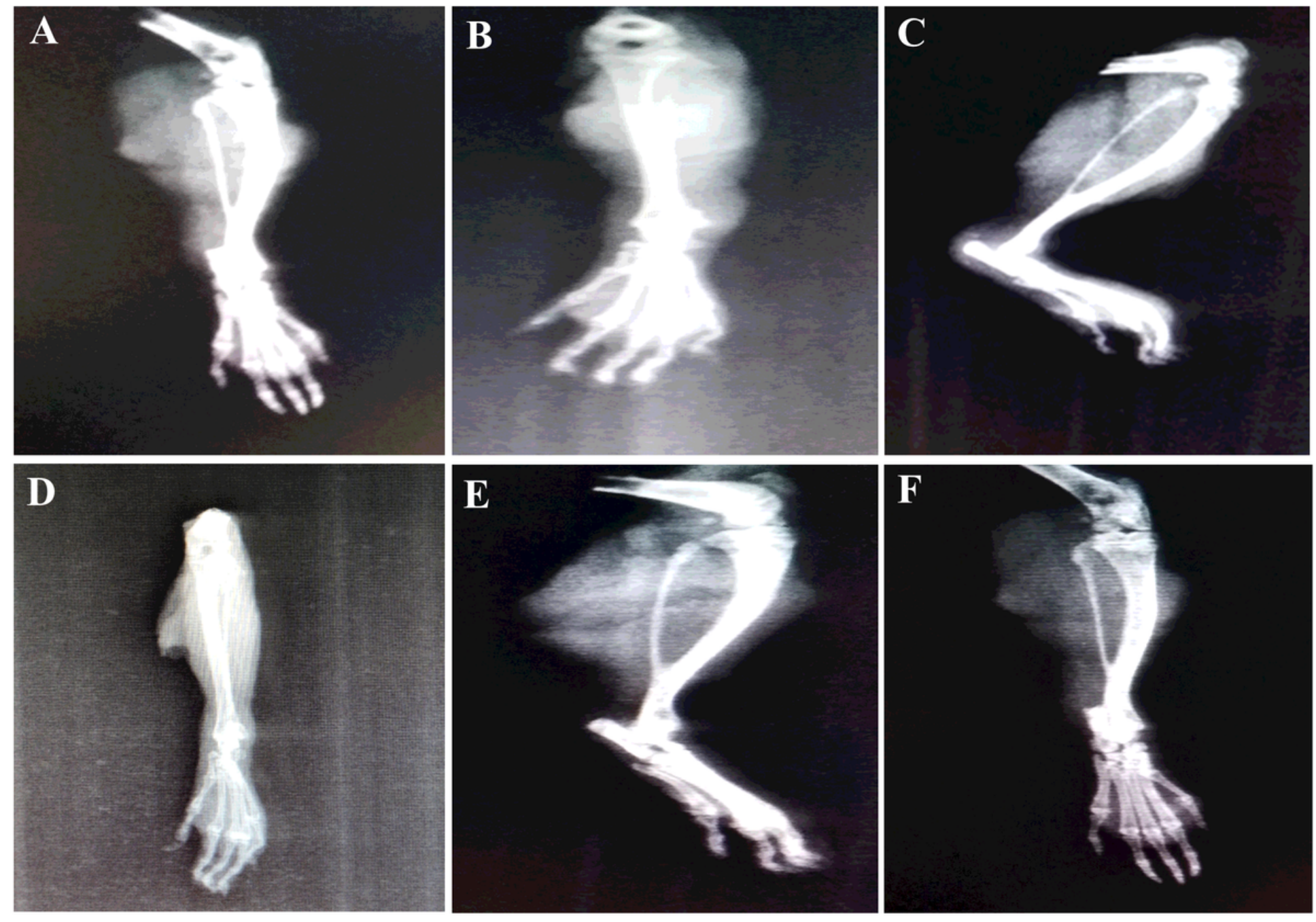

\section{Figure 6}

Pictorial representation of $\mathrm{x}$-ray examination of treated rats versus arthritic control rat. Whereas A represents ankle joint of normal rat with normal morphology and architecture of cartilage, B represents ankle joint of arthritic control rat showed bone erosion and narrowing of joint space, $C$ represents ankle joint of rat treated with naproxen while $D, E$ and $F$ represents ankle joints of treated rats with different doses of nerolidol $(200,400$ and $800 \mathrm{mg} / \mathrm{kg})$ exhibited inhibition of space narrowing and tissue swellings. 